\title{
PENGARUH LEVERAGE, PENURUNAN ARUS KAS OPERASI, FIXEDASSET INTENSITY, DAN PERTUMBUHAN PERUSAHAAN TERHADAP KEPUTUSAN REVALUASI ASET TETAP
}

\author{
M. Haykal ${ }^{1}$, Raudhatul Munira ${ }^{2}$ \\ ${ }_{1,2}^{1,2}$ rodi Akuntansi Fakultas Ekonomi dan Bisnis Universitas Malikussaleh Lhokseumawe \\ mhaykal@unimal.ac.id, raudhatulmunira23011998@gmail.com
}

\begin{abstract}
Abstact: This study aims to examine the effect of leverage, decreased operating cash flow, fixed asset intensity, and company growth on fixed asset revaluation decisions in chemical sub-sector companies listed on 5 ASEAN exchanges in 2017-2019. The data used in this research is secondary data that comes from the financial reports of each stock exchange. The number of samples in this study were 135 observations using purposive sampling technique. Data is accessed through the website www.idx.co.id, www.bursamalaysia.com, www.sgx.com, www.edge.pse.com.ph, and www.set.or.th. Methods of data analysis in this study using logistic regression analysis method. The results showed that fixed asset intensity had a positive and significant effect on fixed asset revaluation decisions, while leverage, decreased operating cash flow, and company growth had no effect on fixed asset revaluation decisions.
\end{abstract}

Keywords : Leverage, Decrease in Operating Cash Flow, Fixed Asset Intensity, Company Growth, and Fixed Asset Revaluation Decisions.

\section{PENDAHULUAN}

Laporan keuangan menjadi media bagi perusahaan untuk menyediakan informasi akuntansi dan pertanggungjawaban atas kinerja yang dicapai perusahaan. Perusahaan dituntut untuk menyediakan informasi yang berkualitas agar tidak menyesatkan para pemangku kepentingan dalam pengambilan keputusan bisnis dan investasi. Pemilihan metode akuntansi yang tepat dapat menyajikan informasi yang bermanfaat bagi pengambilan keputusan serta dapat memastikan bahwa setiap elemen yang tercantum dalam laporan keuangan telah diperlakukan sesuai dengan standar akutansi yang berlaku. Metode akuntansi yang berbeda akan menghasilkan nilai dari setiap elemen laporan keuangan yang berbeda pula, misalnya metode pengukuran aset tetap. Pengadopsian IFRS telah mengakibatkan terjadinya perubahan pada standar akuntansi negara ASEAN. Salah satunya terkait aset tetap, negara ASEAN sudah mengadopsi IAS 16: Property, Plant, and Equipment sesuai dengan standar IFRSyang mendorong penggunaan nilai wajar.

Menurut IAS 16 aset tetap adalah aset berwujud yang: a) dimiliki perusahaan untuk digunakan dalam produksi atau untuk menyediaan barang atau jasa baik direntalkan kepada pihak lain, atau untuk tujuan administratif, dan b) diperkirakan dapat digunakan selama lebih dari satu periode. Standar akuntansi aset tetap mengatur bahwa setelah pengukuran awal aset tetap, perusahaan dapat menentukan apakah menggunakan model biaya (historical cost)atau model revaluasi sebagai kebijakan akuntansinya.

Model biaya mencatat nilai aset tetap sebesar biaya perolehan aset tetap dikurangi akumulasi penyusutan dan akumulasi rugi penurunan nilai. Penggunaan model ini memungkinkan aset tetap kehilangan relavansinya karena nilai aset tetap tidak mencerminkan nilai terkini dan tidak mencerminkan keadaan yang sebenarnya. Terbukti ketika perekonomian mengalami inflasi yang fluktuatif. Inflasi menyebabkan harga barang dan jasa di pasaran naik secara terus menerus. Peralatan yang dibeli 10 tahun yang lalu akan mengalami kenaikan jika dibeli pada saat inflasi. Tanah yang dijual tahun ini mungkin menghasilkan pendapatan cukup besar dibanding kas yang dikeluarkan untuk membeli tanah tersebut 10 tahun lalu. Sehingga penggunaan model biaya mengakibatkan nilai aktiva tercatat dalam neraca memiliki nilai lebih rendah jika dibandingkan dengan perkembangan daya beli uang. Fluktuasi inflasi menyebabkan ketidakrelevan nilai aset jika diukur pada biaya perolehan (historical cost).

Manajemen sebagai pengambil keputusan dapat menentukan kebijakan akuntansi yang lebih mencerminkan relevansi nilai aset tetap yaitu model revaluasi. Berdasarkan model revaluasi, setelah pengakuan awal sebagai aset, aset tetap yang nilai wajarnya dapat diukur secara andal harus dicatat pada jumlah revaluasian, yaitu nilai wajar yang ada pada tanggal revaluasi dikurangi dengan akumulasi penyusutan dan akumulasi penurunan nilai yang terjadi setelah tanggal revaluasi.

Revaluasi adalah penilaian kembali aset tetap perusahaan baik karena meningkatnya nilai aset di pasaran atau menurunnya nilai aset akibat devaluasi atau lainnya, sehingga nilai aset tetap yang tersaji dalam laporan keuangan tidak lagi mencerminkan nilai wajar. Nilai wajar adalah harga yang akan diterima untuk menjual suatu aset atau 
harga yang akan dibayar untuk mengalihkan suatu liabilitas dalam transaksi teratur antara pelaku pasar pada tanggal pengukuran (IAI, 2013). Dengan menggunakan nilai wajar (fair value) dalam pelaporan akuntansi diharapkan dapat meningkatkan kualitas laporan keuangan dan semakin bermanfaat bagi pengguna dalam pengambilan keputusan.

Dikutipdariokezone, pertumbuhan laba komprehensif PT Emdeki Utama Tbk (MDKI) meningkat tajam. Sepanjang 2017, laba komprehensif MDKI ini meroket $347,6 \%$ dari Rp 82,46 miliar menjadi Rp 369,1 miliar. Kenaikan laba komprehensif disebabkan oleh adanya surplus revaluasi atas aset tetap perusahaan, meliputi hak tanah, bangunan, mesin dan peralatan, kendaraan, peralatan pabrik, dan instalasi. Selisih dari nilai wajar dan nilai tercatat kemudian diakui sebagai penghasilan komprehensif dengan nilai mencapai Rp 355,22 miliar. Revaluasiyang dilakukanperusahaanberhasilmenyerap dana sebanyak Rp 22,33 miliar. Dana ini akan digunakan untuk modal kerja dan pembangunan.

Alasan suatu perusahaan memilih metode akuntansi tertentu belum diketahui secara pasti. Riset terdahulu (Cairns et al., 2011) menunjukkan bahwa ketika perusahaan dihadapkan pada pilihan metode akuntansi yang bersifat sukarela, maka perusahaan cenderung untuk memilih metode akuntansi yang bersifat sticky atau sulit berubah. Artinya, perusahaan akan cenderung memilih metode akuntansi yang sama sebelum adanya revisi namun masih diperbolehkan penggunaannya (dalam hal ini metode biaya) dibandingkan dengan alternatif baru (dalam hal ini metode revaluasi). Berdasarkan teori akuntansi positif, penelitian ini mengambil empat variabel yang dianggap dapat mempengaruhi perusahaan memilih metode revaluasi yaitu leverage, penurunan arus kas operasi, fixed asset intensity, dan pertumbuhan perusahaan.

Leverage adalah rasio yang mengukur sejauh mana aset perusahaan dibiayai dengan utang. Leverage digunakan untuk mengukur kemampuan perusahaan untuk membayar utang, baik jangka pendek maupun jangka panjang ketika perusahaan dilikuidasi. Penelitian sebelumnya yang dilakukan oleh (Sitepu \& Silalahi, 2019) menemukan bahwa leverage berpengaruh positif dan signifikan terhadap keputusan perusahaan dalam memilih metode revaluasi aset tetap. Namun berbeda dengan penelitian yang dilakukan oleh (Gunawan \& Nuswandari, 2019) yang menemukan bahwa leverage berpengaruh negatif dan tidak signifikan terhadap keputusan perusahaan memilih metode revaluasi.

Penurunan arus kas operasi adalah perubahan arus kas operasi perusahaan selama 2 tahun dibandingkan dengan aset perusahaan. Penurunan arus kas operasi dapat menyebabkan pemberi pinjaman khawatir dengan likuiditas perusahaan. penelitian yang telah dilakukan oleh (Aziz \& Yuyetta, 2017) menemukan hasil bahwa penurunan arus kas operasi berpengaruh terhadap revaluasi aset tetap. Namun penelitian yang dilakukan oleh (Meiliana \& Febriyanti, 2019) menunjukkan tidak ada pengaruh penurunan arus kas operasi dengan revaluasi aset tetap.

Fixed asset intensity merupakan proporsi aset tetap perusahaan dibandingkan dengan total aset yang dimiliki oleh perusahaan. Penelitian oleh (Gunawan \& Nuswandari, 2019) menemukan adanya pengaruh fixed asset intensity terhadap keputusan revaluasi aset tetap. Namun berbeda dengan penelitian (Aziz \& Yuyetta, 2017) yang menemukan bahwa fixed asset intensity tidak memiliki pengaruh terhadap pemilihan metode ravaluasi aset tetap.

Pertumbuhan perusahaan mengukur seberapa jauh kemampuan perusahaan mempertahankan posisi ekonominya didalam keadaan ekonomi pada umumnya dan didalam industri dimana perusahaan itu termasuk. Penelitian yang dilakukan oleh (Sitepu \& Silalahi, 2019) menemukan adanya pengaruh positif dan signifikan variabel pertumbuhan perusahaan terhadap revaluasi aset tetap. Namun berbeda dengan penelitian (Meiliana \& Febriyanti, 2019) yang menemukan tidak adanya pengaruh pertumbuhan perusahaan terhadap revauasi aset tetap.

Negara pendiri ASEAN adalah 5 negara yang berada di kawasan Asia Tenggara yang meliputi Indonesia, Malaysia, Singapura, Thailand dan Filipina. Kelima negara ini merupakan negara yang mengalami pertumbuhan ekonomi yang paling baik di Asia Tenggara. Oleh karenya, diharapkan dengan pemilihan objek dilima negara Asia Tenggara tersebut dapat mewakili negara Asia Tenggara secara tepat. Perusahaan kimia merupakan subsektor perusahaan manufaktur yang terdaftar di bursa ASEAN. Berdasarkan penelitian yang dilakukan oleh (Purwanto, 2018) dari seluruh perusahaan manufaktur indonesia tahun 2015, 148 perusahaan mengajukan permohonan revaluasi dan 30 perusahaan diantaranya adalah subsektor industri dasar dan kimia.

\section{TINJAUAN PUSTAKA}

\section{A. Landasan Teori \\ Teori Akuntansi Positif}

Teori akuntansi positif mengungkapkan sebuah proses yang menggunakan kemampuan, pemahaman, dan pengetahuan akuntansi serta penggunaan kebijakan akuntansi yang paling sesuai untuk menghadapi kondisi tertentu pada masa yang akan datangMenurut (Watts \& Zimmerman, 1990), teori akuntansi positif mempunyai tiga hipotesis sebagai berikut:

1. Bonus Hypothesis, dalam hipotesis ini diasumsikan bahwa manajemen akan memilih kebijakan akuntansi yang meningkatkan laba yang dapat berpengaruh positif terhadap kompensasi yang akan didapatkannya.

2. Debt Covenant Hypothesis, dalam hipotesis ini diasumsikan manajemen akan memilih kebijakan 
akuntansi yang dapat menghindarkan perusahaan dari pelanggaran persyaratan utang yang diajukan dalam memperoleh pinjaman.

3. Political Cost Hypothesis, diasumsikan bahwa manajemen akan memilih kebijakan akuntansi yang dapat menghindarkan perusahaan dari visibilitas politis yang muncul. Hipotesis ini erat kaitannya dengan ukuran perusahaan.

\section{Revaluasi Aset Tetap}

Revaluasi adalah suatu penyesuaian yang bertujuan untuk mencerminkan kemampuan dan nilai perusahaan yang sebenarnya. Menurut (Judisseno, 2004) revaluasi harta tetap dapat diartikan sebagai penyesuaian harga atau nilai perolehan harta tetap berwujud yang dimiliki dan digunakan dalam perusahaan yang berkenaan dengan adanya perubahan-perubahan dalam perekonomian dan moneter seperti nilai tukar mata uang asing terhadap mata uang rupiah.

Dalam IAS 16 dijelaskan bahwa setelah diakui sebagai aset, aset tetap yang nilai wajarnya dapat diukur secara andal harus dicatat pada jumlah revaluasian, yaitu nilai wajar pada tanggal revaluasian dikurangi akumulasi penyusutan dan akumulasi rugi penurunan nilai yang terjadi setelah tanggal revaluasi Penilaian kembali aktiva tetap perusahaan harus dilakukan berdasarkan nilai pasar atau nilai wajar aktiva tetap tersebut yang berlaku pada saat penilaian kembali yang ditetapkan oleh penilai profesional. Jika jumlah tercatat aset meningkat akibat revaluasi, maka kenaikan tersebut diakui dalam pendapatan koprehensif lain dan terakumulasi dalam ekuitas pada bagian surplus revaluasi. Namun, kenaikan tersebut harus diakui dalam laba rugi hingga sebesar jumlah penurunan nilai aset akibat revaluasi yang pernah diakui sebelumnya dalam laba rugi.

Jika jumlah tercatat aset turun akibat revaluasi, maka penurunan tersebut diakui dalam laba rugi. Namun, penurunan nilai tercatat diakui dalam pendapatan komprehensif lain selama penurunan tersebut tidak melebihi saldo kredit surlpus revaluasi untuk aset tersebut. Penurunan nilai yang diakui dalam pendapatan komprehensif lain mengurangi akumulasi dalam ekuitas pada bagian surplus revaluasi.

\section{Leverage}

Rasio leverage adalah rasio yang digunakan untuk mengukur sejauh mana aktivitas perusahaan dibiayai dengan utang (Kasmir, 2009). Artinya berapa besar beban utang yang ditanggung perusahaan dibandingkan dengan aktivitasnya. Untuk mengukur tingkat leverage, dalam penelitian ini menggunakan jenis debt ratio.
Arus kas operasi melaporkan ringkasan penerimaan dan pengeluaran dari aktivitas operasi. Arus kas dari aktivitas operasi merupakan arus kas yang diperoleh dari aktivitas utama perusahaan. Arus kas dari operasi meliputi transaksi pendapatan dan pengeluaran yang berasal dari penjualan produk atau pemberian jasa layanan yang akan menentukan besar atau kecilnya laba atau rugi bersih. Kegiatan tersebut mencakup arus kas masuk dari penjualan barang, pemberian layanan, pendapatan dividen, pendapatan bunga, serta arus kas keluar untuk persediaan, gaji, pengeluaran pajak, pengeluaran bunga, dan pengeluaran lainnya. Penurunan arus kas operasi dapat dihitung dengan rumus:

$$
\text { CFF0 }=\frac{\text { Perubahan CFFO selama } 2 \text { tahun }}{\text { Total Aset Tetap }}
$$

\section{Fixed Asset Intensity}

Fixed asset intensity menunjukkan jumlah aset tetap yang dimliki oleh perusahaan dibandingkan dengan total aset perusahaan dan menggambarkan banyaknya investasi perusahaan terhadap aset tetap perusahaan. Menurut (Syamsuddin, 2009) intensitas aset tetap adalah penentuan berapa besar alokasi dana untuk masing-masing komponen aktiva, baik dalam aktiva lancar maupun dalam aktiva tetap. Intensitas aset tetap adalah proporsi aset perusahaan yang terdiri dari aktiva tetap (Tay, 2009).Fixed asset intensity diukur dengan rumus:

$$
\text { FAI }=\frac{\text { Total Fixed Asset }}{\text { Total Aset }}
$$

\section{Pertumbuhan Perusahaan}

Pertumbuhan perusahaan dinyatakan sebagai pertumbuhan total aset dimana pertumbuhan masa lalu akan menggambarkan profitabilitas yang akan datang (Hastuti, 2016). Pertumbuhan perusahaan dihitung sebagai persentase perubahan aset pada tahun tertentu terhadap tahun sebelumnya. Menurut (Kusumajaya, 2011) pertumbuhan perusahaan merupakan perubahan total aset baik berupa peningkatan maupun penurunan yang dialami oleh perusahaan selama satu periode. Jadi dapat disimpulkan pertumbuhan perusahaan merupakan perubahan (peningkatan atau penurunan) total aset yang dimiliki perusahaan.

$$
\mathbf{P P}=\frac{\begin{array}{c}
\text { Total Aset Tahun ket }- \\
\text { Total Aset Tahun ke }(\mathrm{t}-1)
\end{array}}{\text { Total Aset Tahun ke }(\mathrm{t}-1)}
$$

\section{B. Hubungan Antar Variabel}

1. Hubungan Revaluasi Aset Tetap dengan Leverage 
Semakin tinggi nilai rasio leverage, menunjukkan bahwa aset perusahaan kurang mencukupi untuk membiayai semua utang perusahaan. Oleh karena itu kreditur lebih menyukai apabila nilai rasio leverage perusahaan rendah agar mereka tidak khawatir terhadap risiko kerugian yang mungkin terjadi jika perusahaan dilikuidasi. Salah satu cara yang dilakukan perusahaan untuk dapat menurunkan rasio leverage adalah dengan menaikan nilai aset perusahaan dengan menggunakan model revaluasi aset tetap. Sesuai dengan Teori Akuntansi Positif yang dikemukakan oleh (Watts \& Zimmerman, 1990), semakin tinggi rasio leverage suatu perusahaan, kemungkinan manajer akan menggunakan metode akuntansi yang dapat meningkatkan nilai aset tetap perusahaan semakin tinggi, sehingga dapat memberikan kepercayaan kepada pihak kreditor atas pinjaman yang dilakukan oleh perusahaan. Menurut (Sugiono \& Untung, 2008) rasio leverage bertujuan untuk menganalisa pembelanjaan yang dilakukan perusahaan berupa komposisi utang dan modal serta kemampuan perusahaan untuk membayar bunga dan beban tetap lainnya.

\section{Hubungan Revaluasi Aset Tetap dengan Penurunan Arus Kas Operasi}

Penurunan nilai arus kas dari kegiatan operasi dibandingkan dengan tahun sebelumnya menyebabkan timbulnya kekhawatiran kreditur. Kekhawatiran tersebut terjadi karena semakin kecil nilai arus kas dari kegiatan operasi, menyebabkan semakin kecil juga kemampuan perusahaan untuk membayar utang yang diberikan oleh kreditur (Aziz dan Yuyetta 2017) menemukan bahwa penurunan arus kas operasi berpengaruh terhadap revaluasi aset tetap perusahaan. Revaluasi aset tetap akan memberikan nilai aset tetap yang lebih tinggi sesuai dengan harga pasarnya sebagai aset penjamin sehingga dapat membantu kreditur yang khawatir karena penurunan nilai arus kas operasi agar lebih yakin dengan melihat kemampuan perusahaaan untuk membayar utang melalui potensi aset tetap yang dimiliki perusahaan. Teori akuntansi positif menyebutkan dalam hipotesis perjanjian kontrak utang bahwa perusahaan akan menghindari pelanggaran kontrak utang agar kreditur tetap mempercayai perusahaan. Oleh karena itu, perusahaan yang mengalami penurunan arus kas operasi akan melakukan revaluasi aset tetap untuk mendapatkan keyakinan dari kreditur.

\section{Hubungan Revaluasi Aset Tetap dengan Fixed Asset Intensity}

Sesuai dengan teori yang dikemukakan oleh (Fields et al., 2001), manajemen melakukan revaluasi aset tetap sebagai upaya untuk mengurangi asimetri informasi dengan principal. Revaluasi akan menyajikan aset tetap pada nilai wajar, sehingga principal dan pemakai laporan keuangan dapat mengetahui posisi terkini aset. Menurut (Sartono,
2016) perusahaan dengan tingkat intensitas aset tetap yang tinggi akan memilih menggunakan revaluasi aset tetap sebagai metode pengukuran dan pengakuan aset tetapnya untuk mencerminkan nilai aset yang sesungguhnya, dan sebaliknya perusahaan dengan tingkat intensitas aset tetap yang rendah cenderung tidak memilih menggunakan revaluasi aset tetap sebagai metode pengukuran dan pengakuan aset tetapnya. Dengan revaluasi, nilai aset tetap perusahaan akan meningkat, sehingga dapat meningkatkan jumlah agunan yang dapat digunakan untuk memperoleh pinjaman.

\section{Hubungan Revaluasi Aset Tetap dengan Pertumbuhan Perusahaan}

Perusahaan dalam kondisi tumbuh digambarkan adanya peningkatan total aset pada tahun ini dari tahun sebelumnya.Menurut (Sartono, 2016) perusahaan dengan tingkat pertumbuhan yang tinggi akan memilih untuk menggunakan revaluasi aset tetap sebagai metode pengukuran dan pengakuan aset tetap perusahannya, sedangkan perusahaan dengan tingkat pertumbuhan yang rendah memilih untuk tidak menggunakan revaluasi aset tetap sebagai metode pengukuran dan pengakuan aset tetap perusahaannya. Karena semakin cepat pertumbuhan perusahaan maka semakin besar kebutuhan dana untuk ekspansi. Semakin besar kebutuhan untuk pembiayaan mendatang maka semakin besar keinginan perusahaan untuk menahan laba.

\section{Kerangka Konseptual}

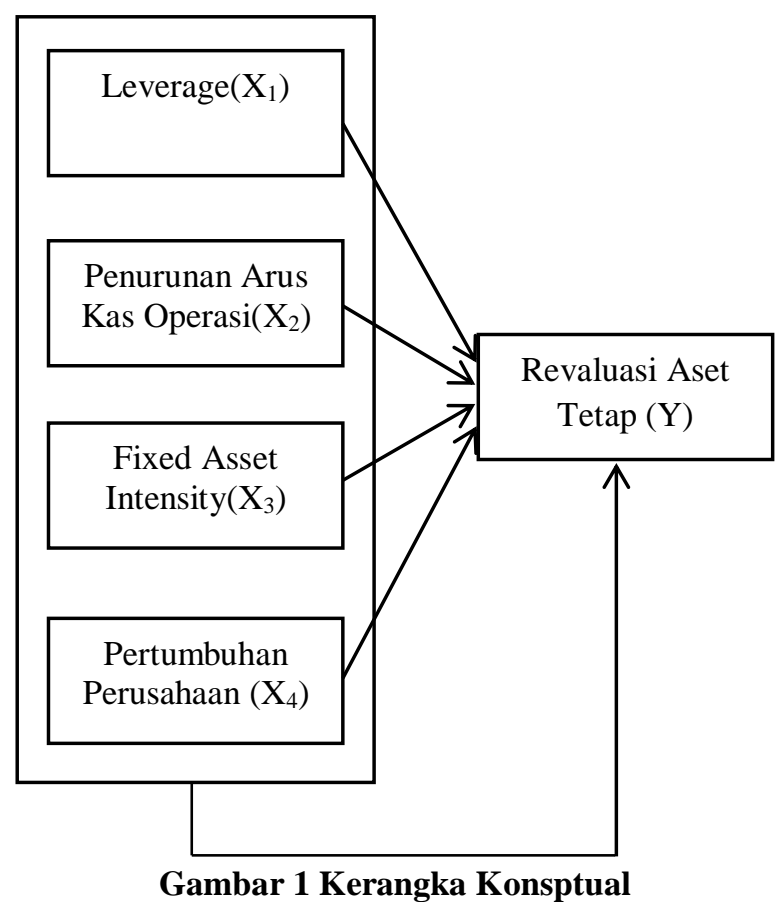

\section{Hipotesis}

H1 : Leverage berpengaruh positif signikan terhadap keputusan revaluasi aset tetap pada subsektor 
kimia yang terdaftar di 5 Bursa ASEAN tahun 2017-2019.

H2 : Penurunan Arus Kas Operasi berpengaruh positif dan signifikan terhadap keputusan revaluasi aset tetap pada subsektor kimia yang terdaftar di 5 Bursa ASEAN tahun 2017-2019.

H3 : Fixed Asset Intensity berpengaruh positif dan signifikan terhadap keputusan revaluasi aset tetap pada subsektor kimia yang terdaftar di 5 Bursa ASEAN tahun 2017-2019.

H4 : Pertumbuhan Perusahaan berpengaruh positif dan signifikan terhadap keputusan revaluasi aset tetap pada subsektor kimia yang terdaftar di 5 Bursa ASEAN tahun 2017-2019.

H5 : Leverage, Penurunan Arus Kas Operasi, Fixed Asset Intensity, dan Pertumbuhan Perusahaan berpengaruh positif dan signifikan terhadap keputusan revaluasi aset tetap pada subsektor kimia yang terdaftar di 5 Bursa ASEAN tahun 2017-2019.

\section{METODOLOGI PENELITIAN Objek dan Lokasi Penelitian}

Dalam penelitian ini yang menjadi objek penelitian adalah Leverage $\left(\mathrm{X}_{1}\right)$, Penurunan Arus Kas Operasi $\left(\mathrm{X}_{2}\right)$, Fixed Asset Intensity $\left(\mathrm{X}_{3}\right)$, Pertumbuhan Perusahaan $\left(\mathrm{X}_{4}\right)$, dan Revaluasi Aset Tetap (Y).

Lokasi penelitian adalah tempat dimana penelitian dilakukan. Penelitian ini dilakukan pada perusahaan manufaktur subsektor kimia yang terdaftar di Bursa Efek Indonesia, Bursa Malaysia, Singapore Exchange, Philippine Stock Exchange, dan Thailand Stock Exchange tahun 2017-2019.

\section{Populasi dan Sampel}

Populasi dalam penelitian ini adalah perusahaan manufaktur subsektor kimia yang terdaftar di Bursa Efek Indonesia, Bursa Malaysia, Singapore Exchange, Philippine Stock Exchange, dan Thailand Stock Exchange tahun 2017 sampai dengan tahun 2019 sebanyak 216 observasi.

Untuk menentukan sampel, penelitian ini menggunakan teknik pengambilan sampel nonprobability sampling dengan metode purposive sampling. Adapun pertimbangan/ kriteria penelitian ini adalah:

1. Perusahaan manufaktur subsektor kimia yang terdaftar di Bursa Efek Indonesia, Bursa Malaysia, Singapore Exchange, Philippine Stock Exchange, dan Thailand Stock Exchange tahun 2017-2019.

2. Memiliki semua data untuk variabel yang digunakan dalam penelitian.

3. Perusahaan listing selama periode penelitian.

Dengan demikian, diketahui jumlah sampel untuk perusahaan subsektor kimia yang terdaftar di bursa ASEAN tahun 2017-2019 adalah 135 perusahaan.

Teknik Analisis Data
Pengujian hipotesis dilakukan dengan menggunakan regresi logistik karena variabel dependen (Y) diukur dengan variabel dummy dan variabel independen $(\mathrm{X})$ berupa variabel kontinyu maupun variabel kategorial. Dimana dalam penggunaan metode regresi logistic tidak perlu adanya uji asumsi klasik pada variabel bebasnya Pengujian hipotesis dapat dilihat dari analisis regresi logistik. Untuk melihat faktor yang mempengaruhi pilihan penggunaan model revaluasi digunakan model regresi logistik sebagai berikut:

$$
\mathrm{PREV}=\alpha+\beta 1 \mathrm{X} 1+\beta 2 \mathrm{X} 2+\beta 3 \mathrm{X} 3+\beta 4 \mathrm{X} 4+\mathrm{e}
$$

Keterangan:

PREV = Probabilitas revaluasi perusahaan (kode 1 jika perusahaanmelakukan revaluasi dan 0 jika perusahaan tidak melakukan revaluasi

$$
\begin{array}{ll}
\alpha & =\text { Konstanta } \\
\beta 1, \beta 2, \beta 3, \beta 4 & =\text { Koefisien regresi } \\
\mathrm{X} 1 & =\text { Leverage } \\
\mathrm{X} 2 & =\text { Penurunan Arus Kas Operasi } \\
\mathrm{X} 3 & =\text { Fixed Asset Intensity } \\
\mathrm{X} 3 & =\text { Pertumbuhan Perusahaan } \\
\mathrm{e} & =\text { Eplison (error term) }
\end{array}
$$

\section{HASIL PENELITIAN DAN PEMBAHASAN Analisis Regresi Logistik \\ Statistik Deskriptif}

Statistik deskriptif digunakan untuk memberikan gambaran umum tentang objek yang dijadikan sampel pada penelitian. Statistif deskriptif menggambarkan hasil data deskriptif statistik yang terdiri dari rata-rata (mean), standar deviasi, maksimum, dan minimum serta jumlah pengamatan.

Tabel 1

Statistik Deskriptif

\begin{tabular}{|l|l|l|l|l|l|}
\hline \multicolumn{2}{|l|}{ Descriptive Statistics } \\
\hline & $\mathrm{N}$ & $\begin{array}{l}\text { Mini } \\
\text { mum }\end{array}$ & $\begin{array}{l}\text { Ma } \\
\text { xim } \\
\text { um }\end{array}$ & Mean & $\begin{array}{l}\text { Std. } \\
\text { Deviation }\end{array}$ \\
\hline Y & 135 & 0 & 1 &, 39 &, 490 \\
\hline LV & 135 &, 06 &, 75 &, 3199 &, 18225 \\
\hline DCFFO & 135 &,- 27 &, 45 &, 0085 &, 09948 \\
\hline FAI & 135 &, 01 &, 87 &, 3232 &, 20485 \\
\hline PP & 135 &,- 49 & 1,61 &, 0725 &, 22443 \\
\hline $\begin{array}{l}\text { Valid N } \\
\text { (listwise) }\end{array}$ & 135 & & & & \\
\hline
\end{tabular}

Sumber: Data diolah (2020)

Tabel 1 menunjukkan jumlah pengamatan (N) dari penelitian ini sebanyak 135 amatan. Variabel dependen yaitu keputusan revaluasi aset tetap memiliki nilai minimum 0 dan nilai maksimum 1 . Nilai rata-rata (mean) diperoleh 0,39 dan standar deviasi sebesar 0,490. Hal ini mengindikasikan bahwa hasil yang tidak normal dan menyebabkan bias karena nilai mean lebih kecil dari standar deviasi. Dengan hasil data tersebut menunjukkan bahwa keputusan revaluasi aset tetap mengalami fluktuasi yang tidak terlalu besar. 
Variabel leverage $\left(\mathrm{X}_{1}\right)$ memiliki nilai minimum sebesar 0,06 dan nilai maksimum sebesar 0,75 . Nilai mean diperoleh 0,3199 dan standar deviasi sebesar 0,18225. Artinya nilai mean yang diperoleh lebih besar dari standar deviasi sehingga penyimpangan data yang terjadi rendah maka penyebaran nilainya merata. Hasil tersebut menunjukkan bahwa leverage mengalami fluktuasi yang besar.

Variabel penurunan arus kas operasi $\left(\mathrm{X}_{2}\right)$ memiliki nilai minimum sebesar $-0,27$ dan nilai maksimum sebesar 0,45 dengan nilai rata-rata (mean) sebesar 0,0085 dan standar deviasi sebesar 0,09948. Karena nilai mean lebih kecil dari standar deviasi, hal ini mengidikasikan bahwa hasil yang tidak normal dan menyebabkan bias. Hasil tersebut menunjukkan bahwa penurunan arus kas operasi mengalami fluktuasi yang tidak terlalu besar.

Variabel fixed asset intensity $\left(\mathrm{X}_{3}\right)$ memiliki nilai minimum sebesar 0,01 dan nilai maksimum sebesar 0,87. Nilai mean diperoleh 0,3232 dan standar deviasi sebesar 0,20485. Nilai mean yang diperoleh lebih besar dari standar deviasi sehingga penyimpangan data yang terjadi rendah maka penyebaran nilainya merata. Hasil tersebut menunjukkan bahwa fixed asset intensity mengalami fluktuasi yang besar.

Variabel pertumbuhan perusahaan $\left(\mathrm{X}_{4}\right)$ memiliki nilai minimum sebesar $-0,49$ dan nilai maksimum sebesar 1,61. Nilai mean diperoleh 0,0725 dan standar deviasi sebesar 0,22443. Karena nilai mean lebih kecil dari standar deviasi, hal ini mengidikasikan bahwa hasil yang tidak normal dan menyebabkan bias. Hasil tersebut menunjukkan bahwa pertumbuhan perusahaan mengalami fluktuasi yang tidak terlalu besar.

\section{UjiKeseluruhanModel(OverallModelFit)}

Uji Overall Model Fit dihitung dengan cara membandingkan nilai -2 Log Likelihood (-2LL)awal (Block Number $=0$ ) dengan nilai -2 Log Likelihood (2LL)akhir (Block Number = 1). Jika terjadinya penurunan dalam -2 LogL (block number $=0-$ block number $=1$ ), maka model yang dihipotesis fit dengan data.

Tabel 2

Overall Model Fit-Awal

\begin{tabular}{|l|c|l|l|}
\hline \multicolumn{3}{|l|}{ Iteration History a,b,c } \\
\hline \multicolumn{2}{|l|}{ Iteration } & -2 Log likelihood & Coefficients \\
\cline { 4 - 5 } & & Constant \\
\hline \multirow{2}{*}{$\begin{array}{l}\text { Step } \\
0\end{array}$} & 1 & 180,873 &,- 430 \\
\cline { 2 - 4 } & 2 & 180,871 &,- 436 \\
\cline { 2 - 4 } & 3 & 180,871 &,- 436 \\
\hline \multicolumn{3}{|l}{ a. Constant is included in the model. } \\
\hline \multicolumn{3}{|l}{ b. Initial -2 Log Likelihood: 180,871 } \\
\hline
\end{tabular}

Sumber: Data diolah (2020)

\begin{tabular}{l} 
Overall Model Fit-Akhir \\
\begin{tabular}{|l|l|l|}
\hline \multicolumn{2}{|l|}{ Iteration History a,b,c,d } \\
\hline Iteration & -2 Log likelihood \\
\hline \multirow{2}{*}{ Step 1} & 1 & 159,412 \\
\cline { 2 - 3 } & 2 & 158,780 \\
\hline & 3 & 158,777 \\
\hline & 4 & 158,777 \\
\hline
\end{tabular} \\
\hline \\
a. Method: Enter \\
\hline c. Constant is included in the model. \\
\hline $\begin{array}{l}\text { d. Estimation terminated at iteration number } 4 \\
\text { because parameter estimates changed by less than } \\
\text {,001. }\end{array}$ \\
\hline
\end{tabular}

Sumber: Data diolah (2020)

Berdasarkan tabel 2 dan 3 dapat dilihat bahwa nilai -2LL awal (Block Number $=0$ ) sebesar 180,871 dan nilai -2LL akhir (Block Number $=1$ ) sebesar 158,777. Hal ini menunjukkan bahwa setelah variabel independen dimasukkan kedalam model nilai -2 log likelihood mengalami penurunan sebesar 22,094 yang artinya penambahan variabel bebas kedalam model regresi mengindikasikan bahwa model semakin baik dan model yang dihipotesis fit dengan data.

\section{Uji Kelayakan Model Regresi (GoodnessofFit Test)}

Uji kelayakan model regresi dinilai dengan menggunakan Hosmer and Lemeshow's Goodness of Fit Test. Model ini digunakan untuk menguji hipotesis nol bahwa data empiris cocok atau sesuai dengan model (tidak ada perbedaan antara model dengan data) sehingga model dapat dikatakan fit.

\section{Tabel 4}

Kelayakan Model Regresi

\begin{tabular}{|l|l|l|l|}
\hline \multicolumn{4}{|l|}{ Hosmer and Lemeshow Test } \\
\hline Step & Chi-square & Df & Sig. \\
\hline 1 & 12,821 & 8 &, 118 \\
\hline
\end{tabular}

Sumber: Data diolah (2020)

Berdasarkan tabel 4 terlihat bahwa nilai signifikan diperoleh 0,118 dimana nilai tersebut lebih besar dari 0,05 . Sehingga dapat disimpulkan bahwa model mampu memprediksi nilai observasinya atau dengan kata lain bahwa model dapat diterimakarena cocokdengandataobservasinya.

\section{Uji Koefisien Determinasi $\left(\mathbf{R}^{2}\right)$}

Uji koefisien determinasi ditentukan dengan melihat Negelkerke's $R$. Square. Uji ini bertujuan untuk melihat seberapa besar variabel independen mampu menjelaskan dan mempengaruhi variabel dependen. 
Tabel 5

Uji Koefisien Determinasi

\begin{tabular}{|l|l|l|l|}
\hline \multicolumn{5}{|c|}{ Model Summary } \\
\hline Step & $\begin{array}{l}-2 \quad \text { Log } \\
\text { likelihood }\end{array}$ & $\begin{array}{l}\text { Cox \& Snell } \\
\text { R Square }\end{array}$ & $\begin{array}{l}\text { Nagelkerke } \\
\text { R Square }\end{array}$ \\
\hline 1 & $158,777^{\mathrm{a}}$ &, 151 &, 205 \\
\hline a. Estimation terminated at iteration number 4 \\
because parameter estimates changed by less than \\
,001.
\end{tabular}

Sumber: Data diolah (2020)

Berdasarkan tabel 5 diketahui nilai Negelkerke'sR.Square sebesar 0,205 atau setara dengan 20,5\%. Sehingga dapat disimpulkan bahwa variabel $\mathrm{X}$ dalam penelitian ini memiliki kemampuan dalam menjelaskan variabel $\mathrm{Y}$ sebesar $20,5 \%$ dan $79,5 \%$ dijelaskan oleh variabel-variabel lain diluar penelitian ini.

\section{Tabel Klasifikasi}

Tabel klasifikasi digunakan untuk menunjukkan kekuatan prediksi dari model regresi. Dalampenelitianini,tabelklasifikasi digunakanuntukmemprediksi kemungkinanrevaluasiasettetapyangdilakukanperusah aan.

Tabel 6

Tabel Klasifikasi

\begin{tabular}{|c|c|c|c|c|c|}
\hline \multicolumn{6}{|c|}{ Classification Table ${ }^{a}$} \\
\hline & \multirow{3}{*}{\multicolumn{2}{|c|}{ Observed }} & \multicolumn{3}{|c|}{ Predicted } \\
\hline & & & \multicolumn{2}{|c|}{$\mathrm{Y}$} & \multirow[b]{2}{*}{$\begin{array}{c}\text { Percent } \\
\text { age } \\
\text { Correct }\end{array}$} \\
\hline & & & $\begin{array}{c}\text { Tidak } \\
\text { Reval } \\
\text { uasi }\end{array}$ & $\begin{array}{c}\text { Revalu } \\
\text { asi }\end{array}$ & \\
\hline $\begin{array}{l}S \\
t\end{array}$ & \multirow[t]{2}{*}{$\mathrm{Y}$} & $\begin{array}{c}\text { Tidak } \\
\text { Revaluasi }\end{array}$ & 69 & 13 & 84,1 \\
\hline $\mathrm{e}$ & & Revaluasi & 30 & 23 & 43,4 \\
\hline $\begin{array}{l}\mathrm{p} \\
1\end{array}$ & & $\begin{array}{c}\text { Overall } \\
\text { Percentage }\end{array}$ & & & 68,1 \\
\hline
\end{tabular}

Sumber: Data diolah (2020)

Berdasarkan tabel 6 terlihat bahwa kekuatan prediksi perusahaan yang tidak melakukan revaluasi aset tetap adalah $84,1 \%$. Hal ini menunjukkan bahwa dari total 82 perusahaan yang tidak melakukan revaluasi, sebanyak 69 perusahaan $(84,1 \%)$ dapat diprediksi oleh model regresi. Sedangkan kekuatan model regresi untuk memprediksi keputusan perusahaan melakukan revaluasi aset tetap adalah sebesar 43,4\%. Hal ini menunjukkan bahwa dari total 53 perusahaan yang melakukan revaluasi aset tetap, sebanyak 23 perusahaan $(43,4 \%)$ dapat diprediksi secara tepat oleh model regresi. Nilai overall percentage sebesar $68,1 \%$ menunjukkan bahwa variabel bebas yang dimasukkan kedalam model yaitu leverage, penurunan arus kas operasi, fixed asset intensity dan pertumbuhan perusahaan dapat digunakan untuk memprediksi keputusan revaluasi aset tetap dengan ketepatan estimasi $68,1 \%$.

\section{Pengujian Hipotesis \\ Uji Hipotesis Secara Parsial}

Pengujian hipotesis dalam penelitian ini bertujuan untuk menguji pengaruh variabel bebas yaitu leverage, penurunan arus kas operasi, fixed asset intensity, dan pertumbuhan perusahaan terhadap variabel terikat yaitu keputusan revaluasi aset tetap dengan menggunakan analisis regresi logistik.

\section{Tabel 7}

Uji Regresi Logistik Secara Parsial

\begin{tabular}{|l|l|l|l|}
\hline \multicolumn{2}{|c|}{ Variables in the Equation } \\
\multicolumn{2}{|c|}{ B } & Sig. \\
\hline \multirow{3}{*}{$\begin{array}{l}\text { Step } \\
1^{\text {a }}\end{array}$} & Leverage & $-2,038$ &, 076 \\
\cline { 2 - 4 } & DCFFO & $-1,279$ &, 512 \\
\cline { 2 - 4 } & FAI & 4,354 &, 000 \\
\cline { 2 - 4 } & PP &, 137 &, 883 \\
\cline { 2 - 4 } & Constant & $-1,260$ &, 008 \\
\hline
\end{tabular}

a. Variable(s) entered on step 1: Leverage, DCFFO, Fixed Asset Intensity, Pertumbuhan Perusahaan. Sumber: Data diolah (2020)

Dari Tabel 7 di atas, maka model regresi logistik yang terbentuk adalah sebagai berikut:

$\mathrm{PREV}=-1,260-2,038 \mathrm{LEV}-1,279 \mathrm{DCCFO}+$ 4,354FAI + 0,137PP + e

Persamaan regresi di atas dapat menjelaskan bahwa:

1. Nilai konstanta model regresi memiliki nilai koefisien negatif sebesar 1,260 yang artinya jika variabel lain dianggap nol atau konstanta maka keputusan revaluasi aset tetap mengalami penurunan 0,826 .

2. Koefisien variabel leverage memiliki nilai negatif sebesar 2,038 dan derajat kebebasan $=1$ yang artinya jika leverage mengalami kenikan $1 \%$ maka keputusan revaluasi aset tetap menurun sebasar 2,038 (203,8\%) begitu juga sebaliknya dengan asumsi variabel independen lainnya tetap.

3. Koefisien variabel penurunan arus kas operasi memiliki nilai negatif sebesar 1,279 dan derajat kebebasan $=1$, artinya jika penurunan arus kas operasi naik $1 \%$ maka keputusan revaluasi aset tetap akun turun sebesar 1,279 (127,9\%) begitu juga sebaliknya dengan asumsi variabel independen lainnya tetap.

4. Koefisien variabel fixed asset intensity memiliki nilai positif sebesar 4,354 dan derajat kebebasan = 1 yang artinya jika fixed asset intensity naik sebesar $1 \%$ maka keputusan revaluasi aset tetap juga akan ikut naik sebesar 4,354 $(435,4 \%)$ begitu juga sebaliknya dengan asumsi variabel independen lainnya tetap.

5. Koefisien variabel pertumbuhan perusahaan memilki nilai positif sebesar 0,137 dan derajat 
kebebasan $=1$, artinya jika pertumbuhan perusahaan mengalami kenaikan sebesar $1 \%$ maka keputusan revaluasi aset tetap akan naik sebesar $0,137(13,7 \%)$ begitu juga sebaliknya dengan asumsi variabel independen lainnya tetap.

Pengujian hipotesis dilakukan dengan melihat taraf signifikan 5\%. Variabel indpenden dikatakan berpengaruh terhadap variabel dependen jika taraf signifikannya $<0,05$. Berdasarkan tabel 4.7 diperoleh hasil uji hipotesis sebagai berikut:

1. Hasil uji regresi logistik untuk variabel leverage diperoleh nilai signifikan 0,076. Apabila dibandingkan dengan $\alpha$ 5\% maka nilai $0,076>$ 0,05 sehingga $\mathrm{H}_{1}$ ditolak. Artinya variabel leverage tidak berpengaruh terhadap keputusan revaluasi aset tetap.

2. Hasil uji regresi logistik untuk variabel penurunan arus kas operasi diperoleh nilai signifikan 0,681. Apabila dibandingkan dengan $\alpha 5 \%$ maka nilai $0,512>0,05$ sehingga $\mathrm{H}_{2}$ ditolak. Hal ini menunjukkan bahwa variabel penurunan arus kas operasi tidak berpengaruh terhadap keputusan revaluasi aset tetap.

3. Hasil uji regresi logistik untuk variabel fixed asset intensity diperoleh nilai signifikan 0,000 yang apabila dibandingkan dengan $\alpha 5 \%$ maka nilai $0,000<0,05$ sehingga $\mathrm{H}_{3}$ diterima. Hal ini menunjukkan variabel fixedasset intensity berpengaruh signifikan terhadap keputusan revaluasi aset tetap.

4. Hasil uji regresi logistik untuk variabel pertumbuhan perusahaan diperoleh nilai signifikan 0,114 yang apabila dibandingkan dengan $\alpha 5 \%$ maka nilai $0,883>0,05$ sehingga $\mathrm{H}_{4}$ ditolak. Hal ini menunjukkan variabel pertumbuhan perusahaan tidak berpengaruh terhadap keputusan revaluasi aset tetap.

\section{Uji Hipotesis Secara Simultan}

Pengujian regresi logistik secara simultan pada penelitian ini dapat dilihat berdasarkan tabel Omnibus Tests of Model Coefficients.Pengujian dilakukan dengan melihat nilai signifikan (p) dengan $(\alpha)=5 \%$. Jika nilai signifikan $<0,05$ maka variabel independen secara simultan berpengaruh terhadap variabel independen. Hasil pengujiannya adalah sebagai berikut:

Tabel 8

Uji Regresi Logistik Secara Simultan Omnibus Tests of Model Coefficients

\begin{tabular}{|l|l|l|l|l|}
\hline \multicolumn{2}{|c|}{} & $\begin{array}{l}\text { Chi- } \\
\text { square }\end{array}$ & Df & Sig. \\
\hline \multirow{2}{*}{$\begin{array}{l}\text { Step } \\
1\end{array}$} & Step & 22,094 & 4 &, 000 \\
\cline { 2 - 5 } & Block & 22,094 & 4 &, 000 \\
\cline { 2 - 5 } & Model & 22,094 & 4 &, 000 \\
\hline
\end{tabular}

Sumber: Data diolah (2020)

Berdasarkan Tabel 8 uji regresi menunjukkan nilai signifikan $0,000<0,05$. Hal ini menunjukkan bahwa variabel independen yaitu leverage, penurunan arus kas operasi, fixed asset intensity, dan pertumbuhan perusahaan secara bersama-sama berpengaruh terhadap variabel independen yaitu revaluasi aset tetap pada perusahaan subsektor kimia yang terdaftar di 5 Bursa ASEAN tahun 2017-2019.

\section{Hasil Pengujian Hipotesis dan Pembahasan \\ Pengaruh Leverage Terhadap Keputusan Revaluasi Aset Tetap}

Hasil penelitian berdasarkan tabel uji regresi logistik menunjukkan bahwa variabel leverage memiliki nilai signifikan $0,076>0,05$ dengan nilai koefisien negatif sebesar -2,038. Dari hasil tersebut dapat diperoleh kesimpulan bahwa variabel leverage tidak berpengaruh terhadap revaluasi aset tetap sehingga $\mathrm{H} 1$ ditolak.

Teori Akuntansi Positif yang dikemukakan oleh (Watts \& Zimmerman, 1990), yang menyatakan bahwa semakin tinggi rasio leverage suatu perusahaan, kemungkinan manajer akan menggunakan metode akuntansi yang dapat meningkatkan nilai aset tetap perusahaan semakin tinggi tidak terbukti dalam penelitian ini. Peningkatan atau penurunan rasio leverage tidak berpengaruh terhadap keputusan perusahaan untuk melakukan revaluasi aset. Kreditur atau pemberi pinjaman kemungkinan tidak terlalu memperhatikan dan memperhitungkan besar kecilnya rasio leverage perusahaan. Tingginya rasio leverage tidak menjadi suatu alasan yang kuat bagi perusahaan untuk melakukan revaluasi aset tetap. (Lin \& Peasnell, 2000) menyatakan bahwa revaluasi yang digunakan sebagai alat akuntansi efektif dalam meningkatkan kapasitas pinjaman tidak dapat dijamin kepastiannya, karena sebagian debtholders dapat mengecualikan revaluasi dalam menghitung rasio utang.

Tidak berpengaruhnya leverage terhadap keputusan untuk melakukan revaluasi aset juga bisa disebabkan karena manajemen perusahaan berusaha melaporkan leverage (baik leverage tinggi maupun rendah) sebagai upaya transparansi kepada publik termasuk kepada kreditur. Pemilihan metode revaluasi aset tetap untuk menghindari kegagalan pembayaran pada perjanjian utang akan mengurangi kredibilitas manajemen dan dapat meningkatkan biaya contracting dimasa depan.

Selain itu, untuk melakukan revaluasi aset tetap perusahaan memerlukan biaya yang cukup besar untuk menilai total aset yang mereka miliki, bisa saja biaya untuk melakukan revaluasi lebih besar dibandingkan dengan nilai pinjaman kredit perusahaan. Disisi lain, perusahaan dengan leverage tinggi lebih fokus untuk menemukan cara bagaimana menghasilkan tambahan riil income untuk mengembalikan pinjaman kepada kreditur dari pada memperoleh income berupa surplus revaluasi yang hanya membuat laporan keuangan menarik dimata kreditur dimana tidak ada uang rill yang masuk ke perusahaan. 


\section{Pengaruh Penurunan Arus Kas Operasi Terhadap Keputusan Revaluasi Aset Tetap}

Berdasarkan pengujian hipotesis yang dilakukan diperoleh nilai siginifikan untuk variabel penurunan arus kas operasi 0,512 >0,05 dengan nilai koefisien negatif sebesar 1,279 sehingga $\mathrm{H}_{2}$ ditolak. Dari hasil tersebut dapat disimpulkan bahwa penurunan arus kas operasi tidak berpengaruh terhadap keputusan revaluasi aset tetap.

Arus kas operasi yaitu arus kas yang berasal dari aktivitas utama perusahaan yang menghasilkan pendapatan perusahaan. Aruskas darioperasi meliputitransaksipendapatandanpengeluaran

yangberasaldaripenjualan produk atau pemberianjasa layananyang akan menentukan besar atau kecilnya laba atau rugi bersih. Berdasakan teori akuntansi positif(Watts \& Zimmerman, 1990), perusahaanyang mengalami penurunan arus kas operasi akan melakukan revaluasi aset tetap untuk mendapatkankeyakinandarikreditur.

Berbanding terbalik dengan teori, penelitian ini menemukan bahwa arus kas operasi tidak berpengaruh signifikan terhadap keputusan revaluasi aset tetap. Hal ini bisa disebabkan karena arus kas dari aktivitas operasi hanya merupakan satu bagian dari arus kas perusahaan secara keseluruhan, sehingga mungkin saja penurunan arus kas dari aktivitas operasi dapat diimbangi oleh aktivitas lainnya seperti aktivitas pendanaan dan aktivitas investasi. Sehingga pemberi pinjaman akan melihat arus kas perusahaan secara keseluruhan dibandingkan hanya berfokus pada arus kas operasi saja (Gunawan \& Nuswandari, 2019).

Tidak berpengaruhnya penurunan arus kas operasi juga bisa disebabkan karena perusahaan lebih berupaya untuk meningkatkan arus kas operasi yaitu dengan mencari tambahan kas secara rill daripada hanya mempercantik laporan keuangan yang mengurangi kredibilitas perusahaan dimata investor. Tidak hanya itu, revaluasi yang dilakukan bisa saja meningkatkan biaya yang tidak sebanding dengan revaluasi yang dilakukan.

\section{Pengaruh Fixed Asset Intensity Terhadap Keputusan Revaluasi Aset Tetap}

Hasil penelitian berdasarkan tabel uji regresi logistik menunjukkan bahwa variabel fixed asset intensity memiliki nilai signifikan $0,000<0,05$ dengan nilai koefisien positif sebesar 4,354 sehingga $\mathrm{H}_{3}$ diterima. Dari hasil tersebut dapat diperoleh kesimpulan bahwa variabel fixed asset intensity berpengaruh positif dan signifikan terhadap revaluasi aset tetap. Artinya semakin besar nilai fixed asset intensity maka semakin besar pula kemungkinan untuk memilih menggunakan metode revaluasi dalam pencatatan aset tetap perusahaan.

Hasil penelitian sesuai dengan hipotesis awal yang menyatakan bahwa perusahaandengantingkatintensitasasettetapyang tinggiakanmemilih

menggunakanrevaluasiaset tetapsebagai metodepengukuran dan pengakuan aset tetapnyauntuk mencerminkan nilai asetyang sesungguhnya. Perusahaan memilih untuk menggunakan model revaluasi aset tetap dalam pencatatan asetnya dikarenakan revaluasi aset tetap dapat meningkatkan nilai aset tetap perusahaan sesuai dengan nilai wajar. Selain itu, fixed asset intensity dapat menggambarkan ekspektasi kas yang dapat diterima jika aset tetap dijual, sehingga perusahaan lebih memprioritaskan metode revaluasi agar mencerminkan nilai aset yang sesungguhnya.

Berpengaruhnya fixed asset intensity terhadap keputusan revaluasi juga bisa disebabkan karena kreditur sangat tertarik dengan basis aset yang kuat. Revaluasi dapat menguatkan basis aset perusahaan sehingga akan menambah tingkat kepercayaan kreditur. Dengan meningkatnya kepercayaan kreditur, meningkat pula kapasitas pinjaman/agunan yang dapat diperoleh perusahaan.

Intensitas aset tetap rendah menandakan porsi aset tetap sedikit jumlahnya dari keseluruhan total aset. Revaluasi tidak cukup berharga dilakukan karena dampak yang ditimbulkan juga tidak besar. Hal ini tidak sebanding dengan biaya untuk melakukan revaluasi yang cukup mahal. Biaya revaluasi menjadi pertimbangan manajemen untuk tidak melakukan revaluasi saat porsi aset tetap sedikit. Hasil penelitian menunjukkan perusahaan dengan kepemilikan aset tetap tinggi akan melakukan revaluasi aset tetap. Sebaliknya, perusahaan dengan proporsi aset tetap rendah, tidak melakukan revaluasi aset tetap.

\section{Pengaruh Pertumbuhan Perusahaan Terhadap Keputusan Revaluasi Aset Tetap}

Hasil penelitian berdasarkan tabel uji regresi logistik menunjukkan bahwa variabel pertumbuhan perusahaan memiliki nilai signifikan $0,883>0,05$ dengan nilai koefisien positif sebesar 0,137 sehingga $\mathrm{H}_{4}$ ditolak. Dari hasil tersebut dapat diperoleh kesimpulan bahwa variabel pertumbuhan perusahaan tidak berpengaruh terhadap revaluasi aset tetap.

Perusahaan dalam kondisi tumbuh digambarkan dengan adanya peningkatan total aset pada tahun tertentu dari tahun sebelumnya. Manajemen melihat bahwa tanpa melakukan revaluasi aset tetap pun, aset mereka sudah mengalami peningkatan dari periode sebelumnya. Jika melakukan revaluasi aset tetap maka akan memperbesar total aset, meningkatkan biaya politis, serta membuat perusahaan lebih "terlihat" sehingga lebih diawasi oleh stakeholder. Revaluasi aset tetap akan menyerap biaya, yang menyebabkan dana perusahaan terpakai untuk membiayai revaluasi. Padahal dalam kondisi tumbuh, perusahaan membutuhkan dana cukup besar untuk meluaskan cakupan bisnis, serta membiayai proyek yang menguntungkan.

Tidak berpengaruhnya pertumbuhan perusahaan terhadap revaluasi mungkin disebabkan 
baik di saat perusahaan tumbuh atau tidak, perusahaan pasti membutuhkan aset tetap untuk menjalankan operasional perusahaan. Teori akuntansi positif yang dikemukakan oleh (Fields et al., 2001) sebagai upaya mengurangi asimetri informasi yang melandasi manajemen melakukan revaluasi juga tidak terbukti. Jika manajemen hendak memberikan informasi nilai wajar aset tetap sebagai upaya mengurangi asimetri informasi, maka perusahaan dapat melakukan revaluasi aset tetap tanpa memandang kondisi perusahaan sedang tumbuh atau tidak.

Tidak adanya pengaruh pertumbuhan perusahaan terhadap revaluasi juga bisa disebabkan karena tinggi rendahnya pertumbuhan perusahaan tidak serta merta membuat nilai wajar aset tetap ikut berubah. Manajemen diprediksi menggunakan model revaluasi agar aset tetap yang tercatat dalam laporan keuangan lebih relevan karena adanya perubahan pada nilai wajarnya. Bukan dikarenakan naik turun atau tinggi rendahnya pertumbuhan perusahaan. Saat nilai aset tetap berubah, perusahaan menggunakan model revaluasi meskipun perusahaan dalam kondisi tumbuh atau tidak.

PengaruhLeverage, Penurunan Arus Kas Operasi, Fixed Asset Intensity, dan Pertumbuhan Perusahaan Terhadap Keputusan Revaluasi Aset Tetap

Hasil penelitian berdasarkan tabel uji regresi logistik secara simultan menunjukkan bahwa variabel leverage, penurunan arus kas operasi, fixed asset intensity, dan pertumbuhan perusahaan memiliki nilai signifikan $0,000<0,05$. Hal ini menunjukkan bahwa variabel independen yaitu leverage, penurunan arus kas operasi, fixed asset intensity, dan pertumbuhan perusahaan secara bersama-sama berpengaruh terhadap keputusan revaluasi aset tetap pada perusahaan subsektor kimia yang terdaftar di 5 Bursa ASEAN tahun 2017-2019, maka hipotesis kelima $\left(\mathrm{H}_{5}\right)$ diterima.

\section{PENUTUP}

Kesimpulan

Berdasarkan hasil penelitian dan pembahasan yang sudah diuraikan di atas, maka peneliti menarik kesimpulan sebagai berikut:

1. Leverage tidak berpengaruh terhadapkeputusanrevaluasiasettetappada subsektorkimiayangterdaftardi

BursaASEANtahun2017-2019.

2. Penurunan Arus Kas Operasi tidak berpengaruh terhadapkeputusanrevaluasiasettetappada subsektorkimiayangterdaftardi BursaASEANtahun2017-2019.

3. Fixed Asset Intensity berpengaruh positif dan signifikan terhadapkeputusanrevaluasiasettetappada subsektorkimiayangterdaftardi 5 BursaASEAN.
4. Pertumbuhan Perusahaan tidak berpengaruh terhadap keputusan revaluasi aset tetap pada subsektor kimia yang terdaftar di 5 Bursa ASEAN tahun 2017-2019.

\section{Keterbatasan Penelitian}

Didalam penelitian ini peneliti menyadari bahwa masih banyak terdapat keterbatasanketerbatasan, antara lain:

1. Nilai Negelkerke's R. Square pada penelitian ini hanya sebesar 0,205 atau setara dengan 20,5\% yang menandakan bahwa 20,5\% variabel dependen dapat dijelaskan oleh variabel independen dan sisanya $74,8 \%$ dijelaskan oleh variabel-variabel lain di luar model penelitian.

2. Penelitian ini hanya meneliti data laporan keuangan subsektor kimia yang terdaftar di 5 Bursa ASEAN, sehingga hasil yang diperoleh terbatas hanya untuk subsektor kimia saja.

\section{Saran}

Berdasarkan pembahasan dan kesimpulan yang diperoleh dari hasil penelitian ini, maka penulis dapat memberikan saran sebagai berikut:

1. Bagi akademisi penulis mengharapkan agar menyediakan sumber referensi atau buku-buku yang berhubungan dengan revaluasi guna terwujudnya tujuan pendidikan yang menghasilkan karya-karya akademik yang bermanfaat bagi perusahaan.

2. Bagi perusahaan subsektor kimia ASEAN penelitian ini diharapkan menjadi pertimbangan dalam pengambilan keputusan mengenai kebijakan yang akan dibuat, terutama kebijakan metode pengukuran aset tetap, karena revaluasi memberikan manfaat bagi perusahaan.

3. Bagi penelitian selanjutnya penulis mengharapkan bahwa penelitian ini dapat dijadikan bukti empiris variabel yang mempengaruhi keputusan revaluasi aset tetap serta dapat dijadikan sebagai bahan referensi bagi penelitian selanjutnya dengan mengembangkan ruang lingkup penelitian seperti penambahan tahun penelitian dan juga penambahan variabel di dalam penelitian seperti ukuran perusahaan, takeover, bonus issue, stakeholder internasional.

\section{KEPUSTAKAAN}

Aziz, N. A., \& Yuyetta, E. N. A. (2017). Analisis Faktor-Faktor Yang Mendorong Perusahaan Merevaluasi Aset Tetap. Diponogoro Journal of Accounting, Vol. 6(No. 4), 1-11.

Cairns, J. E., Impa, S. M., O’Toole, J. C., Jagadish, S. V. K., \& Price, A. H. (2011). Influence of the soil physical environment on rice (Oryza sativa L.) response to drought stress and its implications for drought research. Field Crops Research, 121(3), 303-310. 
https://doi.org/10.1016/j.fcr.2011.01.012

Fields, T. D., Lys, T. Z., \& Vincent, L. (2001). Empirical research on accounting choice. Journal of Accounting and Economics, 31(1-3), 255-307. https://doi.org/10.1016/S01654101(01)00028-3

Gunawan, F., \& Nuswandari, C. (2019). Likuiditas, Leverage, Fixed Assets Intensity, Arus Kas Operasi, dan Ukuran Perusahaan terhadap Pemilihan Model Revaluasi Aset Tetap (Studi Empiris Pada Perusahaan Manufaktur yang Terdaftar di Bursa Efek Indonesia Periode 2013-2017). Dinamika Akuntansi, Keuangan Dan Perbankan, Vol. 8(No. 1), 1-11.

Hastuti, S. (2016). Faktor-faktor yang Mempengaruhi Revaluasi Aset Tetap (Studi pada Perusahaan Sektor infrastruktur, Utilitas, dan Transportasi). Universitas Negeri Semarang.

IAI. (2013). PSAK No. 68 Pengukuran Nilai Wajar. Ikatan Akuntansi Indonesia.

Judisseno, R. K. (2004). Perpajakan (Ed. Revisi) (D. H. Purnomo (ed.)). Jakarta: Gramedia Pustaka Utama.

Kasmir, D. (2009). Pengantar Manajemen Keuangan (Ed. 1). Jakarta: Prenada Media.

Kusumajaya, D. K. O. (2011). Pengaruh Struktur Modal dan Pertumbuhan Perusahaan terhadap Profitabilitas dan Nilai Perusahaan pada Perusahaan Manufaktur di Bursa Efek Indonesia. Universitas Udayana.

Meiliana, R., \& Febriyanti, M. A. (2019). Faktorfaktor yang Mempengaruhi Revaluasi Aset Tetap. Jurnal Akuntansi \& Keuangan, Vol.10(No. 2), 71-98.

Purwanto, H. (2018). Leverage , Ukuran Perusahaan, Dan Fixed Asset Intensity Dan Pajak Penghasilan Dimoderasi Regulasi Insentif Pajak Revaluasi Aset. Jurnal Riset Akuntansi Dan Perpajakan, 5(1), 119-130.

Sartono, A. (2016). Manajemen Keuangan Teori dan Aplikasi. BPPE-Yogyakarta.

Sitepu, H. B., \& Silalahi, E. R. . (2019). Pengaruh Intensitas Aset Tetap, Leverage, Likuiditas, Pertumbuhan Perusahaan dan Ukuran Perusahaan terhadap Revaluasi Aset Tetap pada Perusahaan Manufaktur Sektor Industri Dasar dan Kimia yang Terdaftar di BEI. JRAK, Vol. 5(No. 2), 165-190.

Syamsuddin, L. (2009). Manajemen Keuangan Perusahaan: Konsep Aplikasi dalam: Perencanaan, Pengawasan, dan Pengambilan Keputusan. Jakarta: Rajawali pers.

Tay, I. (2009). Fixed Asset Revaluation : Management
Incentives and Market Reactions. Lincoln University.

Watts, R. L., \& Zimmerman, J. L. (1990). Positive Accounting Theory: A Ten Year Perspective. The Accounting Review, Vol. 65(No. 1), 131156. 
